\title{
HUMAN / SOCIETY'S RIGHT TO INFORMATION ON THE ENVIRONMENT. RECEPTION OF SELECTED ISSUES OF THE AARHUS CONVENTION INTO THE EU AND POLISH LAW
}

\begin{abstract}
The subject of the study is the right to information on the environment. It is a human right, but also a collective right, aimed not only at satisfying curiosity about activities, but also allowing for taking actions aimed at protecting the environment. The purpose of the study is to analyze the provisions of international, EU and Polish law in terms of similarities and differences in legal solutions adopted in the field of access to information on the environment. The research hypothesis is the statement that it is impossible to effectively protect the natural environment against its degradation by human activities without the right to information about that environment. The final conclusions indicated that the social activation is necessary to increase the level of using the right to information on the environment. It is necessary to change the mentality of citizens, but also of public authorities.
\end{abstract}

KEYWORDS: natural environment, right to information on the environment, Aarhus Convention, environmental protection, state of the environment

\section{INTRODUCTION}

The natural environment, since the seventies of the twentieth century, has been a frequent subject of legal regulations not only of individual countries, but also of international organizations, in particular the United Nations 
(hereinafter: the UN) and the European Communities, followed by the European Union (hereinafter: the EU). This tendency has been quite clear since 1986, when a separate title (Title VII) was dedicated to environmental issues for the first time in European treaties (Sitek, 1997, p. 30 and the following).

The United Nations organized several so-called Earth Summits. The most important of them was the Earth Summit of 1992, which took place in Rio de Janeiro. The theme of this summit was the Environment and Development. At that time, the United Nations Framework Convention on Climate Change was adopted, which main goal was to draw attention to the negative effects of climate change (Von Stein, 2008, p. 243 and the following, Kaniewska, 2015, p. 33 and the following). Speaking of the European Union's achievements in this respect, it should be emphasized that it has built the most integrated system of environmental law (Herdegen, 2018, pp. 474-478).

The legislative activities are most often the effects of scientific research conducted on the state of the natural environment related to human activity. Their consequence is an increase in human awareness of the dangers and limited restoration of natural resources (Popiel, Koziara, 2012, p. 30 and the following). The human right, or rather the right of society, to information about the state of the environment is supplementing to the scientific research on the state of the environment, and, as a consequence, to the legislative and institutional solutions, (Kaniewska, Klimski, 2014, p. 475 and the following, Krajewski, 2017, p. 71 and the following).

The human right to information, including information on the environment, has been introduced into the international law, the constitutions of many states, and into the statutory provisions. This regulations were implemented in order to satisfy the curiosity of the individual and society about the activities of public authorities, as well as other entities whose effects are visible in the public sphere, for example - during the construction of a large hotel. This right allows the use of information obtained by the individual or society to take action on threats appearing in various areas of life which are important for the individual and society, in order to protect their own rights. Therefore, there may be also the information on the social or economic sphere (Sitek, 2017, p. 115 and the following, Niedziółka, 2013, p. 193 and the following). 
The natural environment is the sphere which is extremely important for every human being, as well as for all humanity. Therefore, information about the state of the environment and the activities undertaken by public authorities and private individuals which have a significant impact on the natural environment are so important that everyone, regardless of citizenship, has the right to access this information, which is guaranteed in international and national law (Chmaj, 2006, p. 163). Therefore, the subject of the study is to show the essence of the human right to information on the environment. This right gives entitlement to an individual private person, but also to society, even at a micro-scale. The research hypothesis is the statement that it is impossible to effectively protect the natural environment against its degradation by human activities without the right to information about that environment. This right must be perceived in the community and individual dimension.

\section{THE LEGAL GROUNDS FOR THE RIGHT TO INFORMATION ON THE ENVIRONMENT}

The provisions from different level such as the treaty, constitutional and basic level are the legal basis for the human right to information on the environment. In this relatively short study, a comprehensive analysis of all legal provisions in this area is not possible. Thus, in two sections, the basic provisions on the human right to information, including mainly information on the environment, will be presented.

The UNECE Convention on Access to Information, Public Participation in Decision-making and Access to Justice in Environmental Matters is of fundamental importance to the Polish and the EU law. This Convention was concluded on $25^{\text {th }}$ June 1998 in Aarhus, Denmark. Hence this convention is often called the Aarhus Convention. This Convention has been ratified by Poland and by the European Union through the Council Decision of 17 February 2005 on the conclusion, on behalf of the European Community, of the Convention on access to information, public participation in decisionmaking and access to justice in environmental matters (Official Journal of the European Union, L124/1, 17.05.2005). The convention regulates basic issues regarding access to environmental information. In this way, the Aarhus 
Convention became a model solution for other legal regulations in this field (Hartley, Wood, 2005, p. 319 and the following). The solutions contained in it are aimed at activating social participation for environmental protection (Lee, Abbot, 2003, p. 80 and the following).

\section{The right to information on the environment in the light of Polish law}

In the Polish law system, the basis for the right to information is the article 74, paragraph 3 of the Polish Constitution. The constitution-maker stated in it that everyone shall have the right to be informed of the quality of the environment and its protection. This wording has been put into an article that is entirely devoted to the natural environment. Pursuant to the provisions contained therein, two entities may be indicated which are obliged to care for the environment. The first is the public authority. Such a decision was clearly formulated in the article 74, paragraph 2. It is an obvious normative provision. The second entity responsible for the state of the environment is the society. The constitution-maker guarantees the human right to be informed about the natural environment. At the same time, in the same article, in the paragraph 4 , the constitution-maker stated that public authorities shall support the activities of citizens to protect and improve the quality of the environment.

The right to information on the environment, formulated in such way in the Constitution of the Republic of Poland, allows to state that not only a single person has the right to information about the state of the environment, but it is a right mainly with a collective dimension. This means that not only the individual can demand such information, but also the community, usually local, rarely national or international. An entity requesting access to information does not need to demonstrate a legal interest. The natural environment is perceived as a common good, and therefore everyone can individually and collectively request information about the state of the natural environment in order to protect or improve it. Both the individuals and the community should be supported from their activities for the environment by public authorities (Banaszak, 2012, p. 436 and the following).

The provision of article 74 paragraph 3 of the Constitution of the Republic of Poland is a detailed description of the provision of article 
61 of the Constitution, in which the constitution-maker decided that every citizen has the right to be informed about actions taken by public authorities. It follows from the content of this provision, that only Polish citizens and people legally resident in Poland have the right to request access to public information regarding the state and natural protection. (Buliński, Filipowicz, 2017, commentary on the article 5 of the Act of 3 October 2008 on providing information on the environment and its protection, public participation in environmental protection and on environmental impact assessments, Legalis)

A general legal act regulating the access to public information is the Act of $6^{\text {th }}$ September 2001 on access to public information (consolidated text - Journal of Laws of 2019, item 1429). This law regulates basic issues regarding access to public information, regardless of its nature. There, the following issues were defined: the concept of the right to public information, the entities obliged to provide public information and the limitation of the right to public information However, there may be specific provisions regarding specific problem groups, including such as issues related to environmental protection (Bidziński, 2018, p. VII n.). The special legal acts also exist in the system of the EU law, for example - in the field of groundwater protection (De Stefano, 2010, pp. 1332-1340).

Originally, the legal basis for the right to claim the request for the information on the state of the environment was in the Act of $31^{\text {st }}$ January 1980 on the protection and shaping of the environment (Journal of Laws of 1980 , no. 3, item 6). This possibility was included in this Act on the basis of its amendment implemented in 1997 (Journal of Laws of 1997, no. 133, item 885). At that time, the institutions of publicly available registers were introduced which also contained data on the natural environment. The legislator imposed on public authorities an obligation to provide information on the state of the environment and on actions taken in relation to the natural environment even when the inquirer would not be able to demonstrate the legal interest (Raniszewski, 2013, p. 312; Wierzbowski, Rakoczy, 2007, p. 77-78).

Currently, the statutory basis for access to information on the state of the natural environment is the Act of $3^{\text {rd }}$ October 2008 on providing information on the environment and its protection, public participation 
in environmental protection and on environmental impact assessments (consolidated text Journal of Laws of 2018, item 2081). The provision of article 74, paragraph 3 of the Constitution of the Republic of Poland has been transposed into the article 4 of the Act of 3 October 2008 on providing information on the environment and its protection, public participation in environmental protection and on environmental impact assessments. However, the legislator introduced the possibility of statutory restriction of this right. The possibility of a statutory restriction of this right is also introduced in the provision of article. 81 of the Polish Constitution (Rakoczy, 2010, p. 17).

The right to access to the information on environment is yet regulated by other specific legal provisions of a statutory or regulatory status.

\section{The right to information on the environment in the light of EU law}

The basic provision in EU law regarding access to public information is the article 15 of the Treaty on the Functioning of the European Union (Official Journal of the European Union, C326/1, 26.10.2012) (ex Article 255 TEC). This article introduces the principle of openness of the European Union institutions and bodies. This principle is an expression of the concept of good governance, i.e. good administration, and building civil society (paragraph 1). Important for us is the content of the paragraph. 3 of this article, which stipulates that every citizen of the Union and any natural or legal person residing in one of the Member States has the right to access documents of the Union institutions, bodies, offices and agencies. The basic form of document access is making them public. It was also envisaged to introduce legal provisions in the form of ordinances which could restrict access to these documents on grounds of public or private interest.

The European Union has worked out a whole series of legal acts containing wider or narrower solutions regarding the access to public information on the environment. For this reason, I will indicate those which are the most relevant to the discussed issues. The general act is the Regulation (EC) No 1049/2001 of the European Parliament and of the Council of 30 May 2001 regarding public access to European Parliament, Council and Commission documents (Official Journal of the European Union, L145/43, 31.05.2001). It is a general 
legal act that contains rules applicable to specific acts. In the article 2, paragraph 1 of the Regulation 1049/2001, the basic principle of disclosing the public information was included, which is reflected in other legal acts of the Member States, namely, any citizen of the Union, and any natural or legal person residing or having its registered office in a Member State, has a right of access to documents of the institutions, subject to the principles, conditions and limits defined in this Regulation. (Official Journal of the European Union, L145/43, 31.05.2001).

A special act to the above-mentioned Regulation 1049/2001 is the Regulation (EC) No 1367/2006 of the European Parliament and of the Council of 6 September 2006 on the application of the provisions of the Aarhus Convention on Access to Information, Public Participation in Decision-making and Access to Justice in Environmental Matters to Community institutions and bodies (Official Journal of the European Union, L264/13, 25.09.2006). This regulation sets out the rules for implementing the obligations arising from the Aarhus Convention. In particular, the right of access to the information on environment and the methods of publication of this information are guaranteed. This regulation stipulates that every citizen of the European Union, as well as any natural or legal person residing or having its registered office in one of the Member States, has the right to access documents of the EU institutions also in the field of the environment.

The next step is the Directive 2003/4/EC of the European Parliament and of the Council of 28 January 2003 on public access to environmental information and repealing Council Directive 90/313/EEC (Official Journal of the European Union, L41/26, 13.02.2003). The purpose of the Directive is harmonization of provisions regarding the right of access to environmental information. The purpose of the directive was to guarantee public access to environmental information. Basic conditions and practices regarding the implementation of the right of access to information on the environment would be defined. The provisions contained in this directive contain so-called minimum standards. This means that the individual Member States may introduce different solutions, which, however, cannot be lower than those included in Directive 2003/4 / EC. 


\section{THE MATERIAL SCOPE OF THE RIGHT TO INFORMATION ON THE ENVIRONMENT}

The material scope of the right to environmental information is very wide. The model for those legal acts is the article 2, paragraph 3 of the Aarhus Convention. At the very beginning, it was decided that the phrase "environmental information" includes any information in written, visual, verbal, electronic and any other material form.

In the article 2, paragraph 3 of the Aarhus Convention, the model scope of matters covered by the right of access to information on the environment has also been marked. It was decided there that the right of access to environmental information includes:

a) the state of elements of the environment, such as air and atmosphere, water, soil, land, landscape and natural sites, biological diversity and its components, including genetically modified organisms, and the interaction among these elements;

b) factors, such as substances, energy, noise and radiation, and activities or measures, including administrative measures, environmental agreements, policies, legislation, plans and programmes, affecting or likely to affect the elements of the environment within the scope of subparagraph (a) above, and cost-benefit and other economic analyses and assumptions used in environmental decision-making;

c) the state of human health and safety, conditions of human life, cultural sites and built structures, inasmuch as they are or may be affected -3- by the state of the elements of the environment or, through these elements, by the factors, activities or measures referred to in subparagraph (b) above.

\section{THE FORMAL ELEMENTS OF THE RIGHT TO INFORMATION}

The access to environmental information may be made upon a request in any form. It can therefore be in oral or written form. In the first case, we are dealing with a situation in which a questioner can personally appear in a public authority or communicate with that authority by another means of direct communication, for example - a telephone or a visual connection device. The written form may take the traditional form, i.e. a letter addressed 
to the office by post. It can also be a request addressed to public authorities via e-mail or social messenger such as Facebook, or via a trusted profile by ePUAP.

In the article 4, paragraph 1 of the Aarhaus Convention, it was decided that a request for access to environmental information may be made without showing any legal interest. The international legislator does not impose any requirements as to the form of the application itself or the response. The public authority may provide a response in a different form to that which would result from the applicant's request, but in this case it must justify its decision. Another form of response may also result from the fact that the information requested is already publicly available.

The Aarhus Convention provides cases for refusals to provide the environmental information (the article 4, paragraph 4). Such a refusal may take place when:

a) this is related to the confidentiality of pending proceedings conducted by public authorities,

b) the criminal or disciplinary investigation is in process,

c) this requires the preservation of industrial trade secrets,

d) this is related to the protection of intellectual property rights,

e) or this information applies to breeding sites of rare species of birds or animals.

In the Polish law, the issue of refusal to provide information on the environment has been regulated in the article 16, paragraph 1 of the Act on providing information on the environment and its protection, public participation in environmental protection and on environmental impact assessments. The Polish legislator additionally introduced further criteria to refuse to provide such data. Namely, the refusal may result from the need to ensure public security, guarantee national defence and security, and protect statistical confidentiality provided by the provisions on public statistics.

The issue of providing the information which result from the right to access to the environmental information, requires public authorities to collect this data. The Aarhaus Convention in the article 5, paragraph 1 imposes on public authorities the obligation to collect and update environmental information within their competence. 
The implementation of this obligation is possible when the public authority maintains lists, registers or data sets. And in fact, the European Union aggregates such data in various areas of the natural environment. And so, the data on individual species of birds and animals are collected, as well as data on the quality of the environment and on possible threats to it. The basic database for such data is EUROSTAT.

In the Act of $3^{\text {rd }}$ October 2008 on providing information on the environment and its protection, public participation in environmental protection and on environmental impact assessments, the Polish legislator speaks about numerous registers publicly available and functioning on the basis of separate provisions. The Act of $27^{\text {th }}$ April 2007 on environmental protection is of key importance (consolidated text - Journal of Laws 2019, item 1396). Among other things, it refers to a register containing information about areas at risk of mass movements and about areas where these movements occur. There is also the register of hazardous substances.

On the basis of the Act of $13^{\text {th }}$ September 1996 on maintaining cleanliness and order in municipalities (Journal of Laws of 2018, items 1454 and 1629), in the regulation on applications for entry in the register of regulated activities in the field of municipal waste collection from property owners and entries in this register, the record of registered, particularly dangerous activity is kept. In the Act of $20^{\text {th }}$ July 1991 on the Environmental Protection Inspection (Journal of Laws of 2018, items 1471 and 1479), the register of major accidents was introduced, in the Act of $12^{\text {th }}$ June 2015 on the greenhouse gas emission allowance trading system (Journal of Laws of 2018 , item 1201), the register of direct threats to environmental damage and the environmental damages mentioned in the article 26a, paragraph 1 was introduced, in the Act of $22^{\text {nd }}$ June 2001 on microorganisms and genetically modified organisms, the following registers were introduced: the Register of Genetic Engineering Establishments, the Register of the Closed Use of Genetically Modified Microorganisms, the Register of the Closed Use of Genetically Modified Organisms, the Register of Intentional Release of Genetically Modified Organisms to the Environment, the Register of Genetically Organized Products and the Register of GMO Crop Registry. 
Based on the article 128 of the Act on providing information on the environment and its protection, public participation in environmental protection and on environmental impact assessments, the General Director for Environmental Protection is obliged to maintain a database on environmental impact assessments. This database should contain information on the strategic environmental impact assessments and the environmental impact assessments of planned projects, as well as assessment of the impact of projects implemented in the Natura 2000 area. This database is conducted in the IT system based on the article 3 of the Act of $17^{\text {th }}$ February 2005 on information about the activities of entities performing public tasks (consolidated text - Journal of Laws 2019 item 700 and 730).

The collected data should be regularly published. In particular, in accordance with the article 5, paragraph 4 of the Aarhus Convention, the following documents are to be compulsory published:

a) the legislation and documents such as strategy texts, policy guidelines, programs and action plans with environmental relevance, and progress reports on their implementation at various levels of public administration,

b) the international treaties, conventions and agreements relating to environmental matters;

c) other important international documents relating to environmental matters, if applicable.

The access to information may be in oral, written, visual, audio, electronic or other form (the article 9, paragraph 2 of the Act of 3 October 2008 on providing information on the environment and its protection, public participation in environmental protection and on environmental impact assessments).

The information requested by a party from the public authority should be made available as soon as possible, but no longer than within 1 month. If it is necessary to obtain the requested information, this period may be extended to 2 months (the article 2, paragraph 2 of the Aarhus Convention). An analogous provision has been included in the article 14 paragraph 1 and 2 of the Act on providing information on the environment and its protection, public participation in environmental protection and on environmental 
impact assessments. In the case of extension of the deadline for waiting for an answer, the public authority is required to inform the applicant of the reasons for the extension (the article 4, paragraph 2 of the Aarhus Convention and the article 35 paragraph 5 and the article 36 of the Code of Administrative Procedure).

In order to streamline the process of providing public information on the environment, the public authorities are required to appoint a special person for this purpose (the article 10 of the Act of 3 October 2008 on providing information on the environment and its protection, public participation in environmental protection and on environmental impact assessments). This normative solution means that the aggregation of data and the process of making it public is a cost. The Aarhus Convention has adopted a solution that providing of environmental information is free. Thus, an analogous solution was adopted in the EU and the Polish law.

As the rule, providing environmental information is free. However, this only applies to searching and browsing data at the seat of public authorities. If answering would generate costs, such as copying documents, processing data, special data collection which has not been collected so far, the authority may charge a fee reflecting the reasonable costs involved (the article 4 paragraph 8 of the Aarhus Convention and the article 26 of the Act of 3 October 2008 on providing information on the environment and its protection, public participation in environmental protection and on environmental impact assessments).

\section{Conclusions}

The natural environment is necessary for human life in both individual and collective dimensions. It is necessary for the survival of future generations. This obvious statement indicates that the human being and the society are vitally interested in the state of the environment, in the actions aimed at environmental protection, as well as in the actions of public, state and local government authorities and the private entities, if these activities are carried out in a public area, for example - the construction of a hotel. On this basis, people and all communities have the right to request information on the state of the environment. 
The right to information on the environment is the human right guaranteed in the international, the $\mathrm{EU}$ and the national legal regulations. The Aarhus Convention of 1998 is of fundamental importance in this respect. The provisions contained in this Convention are model for the EU and the Polish law, as well as for the regulations of other countries which have ratified the Convention. An important provision of this convention is the free sharing of this information. The possibility of access to information is also an opportunity to build not only civil society, but above all it gives a chance to increase awareness and increase social activity to protect or save the environment from its degradation as a result of human activity. Often, the consequences of excessive human expansion into the environment are not realized. Unfortunately, despite the fairly good legal basis, the effectiveness of exercising the right to information on the environment is relatively low. This is the result of a lack of adequate social awareness, but also a reluctance to share this information by public authorities or private entities conducting their activities in the public area. It is therefore necessary to expand the legal basis, thanks to which it will be possible to create instruments activating society in this respect.

\section{References}

Banaszak, B. (2012). Konstytucja Rzeczpospolitej Polskiej. Komentarz, Warszawa: C.H. Beck, p. 436 and the following. ISBN 9788325540951.

Bidziński, M., Chmaj, M., Szustakiewicz, P. (2018). Ustawa o dostępie do informacji publicznej. Komentarz, Warszawa: C.H. Beck. Legalis. ISBN 9788325516321.

Chmaj, M. (ed.). 2006. Wolności i prawa człowieka w Konstytucji Rzeczpospolitej Polskiej, Warszawa: Wolters Kluwer. ISBN 8374443154.

De Stefano, L. (2010). Facing the water framework directive challenges: a baseline of stakeholder participation in the European Union. Journal of environmental management, 91(6), 1332-1340. ISNN 2398-2659.

Filipowicz, T., Plucińska-Filipowicz, A., Wierzbowski, M. (2017). Ustawa o udostępnianiu informacji o środowisku $i$ jego ochronie, udziale społeczeństwa $w$ ochronie środowiska oraz o ocenach oddzialywania na środowisko. Komentarz, Warszawa: C.H. Beck. Legalis.

Hartley, N., Wood, C. (2005). Public participation in environmental impact assessment-implementing the Aarhus Convention. Environmental Impact Assessment Review, 25(4), 319-340. ISNN 0195-9255. 
Herdegen, M. (2018), Europarecht, Munchen: C.H. Beck, ISBN 9783405726194.

Kaniewska, M. (2015). Zmiany klimatu jako wyzwanie do etycznego działania. Journal of Modern Science, 27(4), 33-49. ISSN 1734-2031.

Kaniewska, M., \& Klimski, M. (2014). Kształtowanie świadomości ekologicznej-perspektywa lifelong learning, Journal of Modern Science, 3(22), 475-489. ISSN 17342031.

Krajewski, P. (2017). Prawo człowieka do środowiska jako potrzeba wielowymiarowych zależności i relacji człowieka z otoczeniem. [in:] E. Ura, B. Sitek, T. Graca, Potrzeby jako współczesny determinant treści praw człowieka, Józefów: WSGE pp. 71-86. ISBN 9788362753864.

Lee, M., \& Abbot, C. (2003). The usual suspects? Public participation under the Aarhus Convention. The Modern Law Review, 66(1), 80-108. ISNN 0026-7961.

Niedziółka, I. (2013). Bezpieczeństwo konsumentów w aspekcie społecznym, [in:] M. Such-Pyrgiel (ed.), Bezpieczeństwo społeczne w XXI wieku w ujęciu socjologicznym, pedagogicznym, prawnym i nauk o zarządzaniu, pp. 193-203, Józefów: WSGE. ISBN 9788362753376.

Popiel, H., Koziara, M. (2012). Zagrożenie dla środowiska naturalnego w związku z prowadzeniem działalności gospodarczej. Nowoczesne systemy zarządzania, 7, pp. 29-46. ISNN 1896-9380.

Rakoczy, B. (2010). Ustawa o udostępnianiu informacji o środowisku i jego ochronie, udziale społeczeństwa $w$ ochronie środowiska oraz o ocenach oddziaływania na środowisko Komentarz Lexis Nexis Warszawa. ISBN 9788376204291.

Raniszewski, S. (2013). Prawo dostępu do informacji o środowisku i jego ochronie, Studia z Zakresu Prawa, Administracji i Zarządzania UKW, vol. 4, p. 318. ISNN 2299-6338.

Sitek, M. (2017). Ekologiczny rozwój gospodarki szansa na wzrost zatrudnienia w Unii Europejskiej. Journal of Modern Science, 33(2), 115-128. ISSN 1734-2031.

Sitek, M. (1997). Problemy ekologii w polityce prawnej i prawie Wspólnoty Europejskiej. Wkład do Europejskiej kultury prawnej, Toruń: Wit-Graf. ISBN 8390136791.

Von Stein, J. (2008). The international law and politics of climate change: Ratification of the United Nations Framework Convention and the Kyoto Protocol. Journal of Conflict Resolution, 52(2), 243-268. ISNN 0022-0027

Wierzbowski, B., Rakoczy, B. (2007. Podstawy prawa ochrony środowiska, Warszawa: LexisNexis. ISBN 978-83-7334-750-2.

Wójcicka, M. Łęski, M. (2015). The concept of sustainable development in the UN activity, [in:] M. Sitek, M. Wójcicka ed.), Collective human rights, Józefów: WSGE. pp. 341-354. ISBN 9788362753734. 